lowered the stocking capacity that overstocking on established farms is now almost unavoidable. Rabbits have added to the evil, the vegetation cannot recover after grazing, and natural regeneration of both shrubs and grasses has virtually ceased. Large areas have become barren deserts, and no measures are available for their reclamation. The evil might be checked by adopting a lower stocking policy; but the only hope for the already denuded areas is to introduce perennial exotic plants capable of stabilizing the large sand drifts, and withstanding rabbits and a very low and uncertain rainfall. The chance of discovering such plants is remote, and even if discovered, "there would remain the problem of their dissemination through vast areas with no regular growing season and an unimproved capital value rarely exceeding 2s. per acre".

\section{Mining in Canada}

WE have received the Report of the Department of Mines of the Dominion of Canada for the fiscal year ended March 31, 1935, and taken as a whole it may be said to be thoroughly satisfactory. The Report shows that the rise in the price of gold has caused renewed activity in that industry and states that "Canada's gold industry is contributing to the prosperity, not only of the communities in which operations are centred, but to the industrial life of the nation as a whole". Canada apparently is also reopening some of the silver camps for which it was famous a few years ago, but the "Department's work in fuels and non-metallics is becoming of increasing economic importance", and there has been a relatively small number of ore treatment investigations in connexion with base metal ores. There are full reports of the various divisions of the Department of Mines, commencing with a Bureau of Economic Geology, the National Museum of Canada and Mines Branches proper, together with an Explosives Division, an Editorial Division and an Accounting Division, which latter shows that something like a million dollars was available for the expenditure of the Department of Mines, and that nearly all of it was utilized. It is interesting to note that the Fuels and Fuel Testing Division was busily engaged throughout the year in question.

\section{Cotton Research in India}

INDIA is the second largest cotton growing country in the world, and the importance of the industry led the Indian Cotton Committee to set up a Technological Laboratory at Matunga some ten years ago. Research work and tests of direct importance to the cotton breeder, merchant and mill owner have been carried out in collaboration with the provineial agricultural departments, and a brochure has just been published by the Committee giving a full account of the activities of the Laboratory since its inception (Bombay: Indian Central Cotton Committee. 2 rupees). The two main objects of the work are to undertake spinning tests on improved varieties of cotton, and to establish relationships between the measurable fibre characteristics and the spinning quality. This second object aims at dispensing with the necessity of making spinning tests on large numbers of new strains, as it is hoped to be able to assess the performance of the cotton from a knowledge of its fibre properties. The development of the work may be judged from the fact that during 1933-34, 166 samples were tested in connexion with trade and technological problems, compared with only 28 in 1924-25, while as regards agricultural samples, 366 were tested in 1933-34, compared with 46 in the 1924-25 season. The problem of averting the possible danger of the introduction of the cotton bollweevil through imported American bales has been successfully attacked. A satisfactory method of fumigation has been developed, and legislation enacted to ensure that all cottons imported from America are so treated. The brochure concludes with a complete list of publications issued from the Laboratory since 1925.

\section{The Science Museum Library}

ON entering a library for the purpose of obtaining information on a given subject, the first things the visitor wishes to know are what books or pamphlets the library possesses relating to the subject, and how is he to obtain them. There are usually card indexes available, but even with these at his disposal the reader may well be at sea unless he possesses a key to the system on which they are arranged. The publication of a new edition of the "Classification for Works on Pure and Applied Science in the Science Museum Library" (London : H.M. Stationery Office. 5s. net.) provides such a key to the finest science library in Great Britain. It should be studied by every one who uses the Library. It contains an explanation of the Universal Decimal Classification of the International Institute of Documentation in use at the Library, a list of about six thousand classes into which knowledge is divided for the purpose of indexing, and a copious alphabetical index comprising some five thousand entries. In the preface to the "Classification", Dr. S. C. Bradford says : "The titles on the cards in the Subject Catalogue are numbered and arranged in accordance with the Universal Decimal Classification. Under each number the titles are in chronological order. To ascertain what books the Library possesses on a given subject, readers are recommended to look first in the index, and then refer to the classification, before consulting the cards." By following this advice, those not already familiar with the system used in the Science Museum Library will undoubtedly save themselves both time and labour. It may be added that, in the last Report on the Science Museum, it was stated that the Library now possesses 252,515 volumes, the total of periodicals currently received is 9,468 , while the Subject Matter Index contains 2,248,423 references.

\section{Progress in France of Electricity Supply}

AN account of electricity supply in France appears in World Power of July, as a translation of a paper in La Journée Industrielle. In 1923 the total installed capacity of electrical generating stations was $4 \frac{1}{2}$ million kilowatts. This increased to $10 \frac{1}{2}$ million in 1935. There are 15 thermal and 5 hydro-electric 